\title{
Review of acridity in taro [Colocasia esculenta (L) Schott]: Its health and economic impact, and possible reduction mechanisms
}

\author{
Tilahun Wondimu Fufa $^{1 \star}$, Happiness Ogba Oselebe ${ }^{2}$, Wosene Gebreselassie Abetw ${ }^{3}$ and \\ Charles Okechukwu Amadi ${ }^{4}$
}

\author{
${ }^{1}$ Departement of Horticulture, Oromia Agricultural Research Institute, Addis Ababa, Ethiopia. \\ 2Department of Crop Production and Landscape Management, University of Ebonyi State, Abakaliki, Nigeria. \\ ${ }^{3}$ Departement of Horticulture and Plant Science, Jimma University, Jimma, Ethiopia. \\ ${ }^{4}$ Department of Cocoyam Improvement, National Root Crops Research Institute, Umudike, Nigeria.
}

${ }^{*}$ Corresponding author. Email: bekatilahun@gmail.com

Copyright (C) 2021 Fufa et al. This article remains permanently open access under the terms of the Creative Commons Attribution License 4.0, which permits unrestricted use, distribution, and reproduction in any medium, provided the original work is properly cited.

Received 2nd September, 2021; Accepted 28th September, 2021

\begin{abstract}
S: Taro is primarily grown for the corm, which is a staple food for millions of people. It is an annual herbaceous plant that belongs to the oxalate-rich food group. Oxalate is a naturally occurring plant metabolite that is present in all plant-derived human diets. The accumulation of oxalate by crops and pasture plants has a negative impact on the nutritional quality of foods and feeds. Oxalate is a poisonous organic acid that has a significant impact on the eating quality. Acridity causes swelling of the mouth and throat. Oxalate-rich foods also reduce calcium bioavailability and increase the risk of kidney stones. About $75 \%$ of all kidney stones are made up primarily of calcium oxalate. Chronic kidney disease affects $10 \%$ of the global population, and over two million people currently receive dialysis or a kidney transplant. Oxalates in food can be reduced through physical processes, chemical treatments, and genetic improvements. Cooking root crops may improve digestibility, palatability, storage quality, and safety. Boiling significantly reduced the amount of anti-nutritional factors, resulting in higher food quality. Eating high-calcium foods and adding calcium to cooking are two other ways to reduce oxalates in the diet. Calcium salts are widely accepted and used as acidity regulators, firming agents, and stabilizers in processed foods. Taro corms' total soluble oxalate content also decreased during storage. Explicitly, genetic advancements can aid in the development of long-term solutions. The purpose of this paper was to investigate acridity, its health and economic consequences, and potential food-acridity-reduction mechanisms. This educates users about the dangers of oxalate and aids in the development of mitigation strategies.
\end{abstract}

Keywords: Bioavailability, cooking, food, kidney stone, oxalate, quality.

\section{INTRODUCTION}

Taro is an annual herbaceous plant that belongs to the oxalate-rich food group (El-Monairy, 2015). The accumulation of oxalate in taro plants has a negative impact on its nutritional quality. Oxalic acid is a food toxin with negative effects on human nutrition. If consumed fresh, it causes acridity and swelling of the lips, mouth, and throat tissues (Oscarsson and Savage, 2007). Eating oxalate-rich foods also reduces calcium bioavailability and leads to kidney stone formation (Libert, 1987a). Chronic kidney disease affects $10 \%$ of the global population and over two million people currently receive dialysis or a kidney transplant to stay alive (Thomas, 2019). Chronic Kidney stone treatments have high economic implication both in developed and developing countries.

Physical methods such as soaking, boiling, and cooking can be used to remove oxalates from food (Oscarsson and Savage, 2007). Uses of chemical processes such as adding calcium during cooking, or adding calcium salts during food manufacturing can reduce the acridity of food. Above all, breeding to improve the crop's acridity content can permanently solve acridity problems (Lebot et al., 2004). In this regard, taro has a moderate genetic diversity, 
and exhausting this diversity could lead to the development of cultivars with high corm quality. Possession of low acridity and high dry matter are basic quality characteristics in taro plant. People who have previously formed stones are advised to avoid foods high in sodium because they cause calcium excretion. They are also advised not to consume foods high in oxalate. Thus, the purpose of this paper was to investigate acridity, its health and economic consequences, and potential foodacridity-reduction mechanisms. This educates users about the dangers of oxalate and aids in the development of mitigation strategies.

\section{THE TARO AND ITS ACRIDITY}

\section{The taro}

Taro is an annual herbaceous plant in the oxalate-rich food group (El-Monairy, 2015). It is grown primarily for its corm, which is a staple food for millions of people (Oscarsson and Savage, 2007). It is the third root crop in the Araceae family grown in West Africa, following yam and cassava (Nwanekezi et al., 2010). Despite its adaptation to tropical conditions, it has long been grown in parts of Europe and the Mediterranean (Oscarsson and Savage, 2007). It is currently cultivated in subtropical and tropical regions for its edible carbohydrate-rich tuber, which is the most eaten part of the plant and is formed underground (Simsek and El, 2015). Other plant tissues, such as leaves, flowers, and stems, are consumed depending on the variety and local cultural traditions, particularly in sauces, purees, stews, and soups. It is known by various names in different parts of the world (Bradbury and Holloway, 1988). Cocoyam is a collective term for taro and tannia, the two most important edible aroids with high oxalate contents (Bradbury et al., 1988).

Despite the wide application and great potential of taro as a chief dietary source of carbohydrate and other essential nutrients, its usage is often limited by low productivity and anti-nutrient contents which are either potentially toxic or may limit the bioavailability of nutrients (Alcantara et al., 2013). Apparently, taro leaves and corms are ridiculous in anti-nutritive factor exclusively oxalate (Oscarsson and Savage, 2007). Oxalate is a deadly organic acid (Lewu et al., 2009) and its accumulation in taro plants impacts their nutritional quality, producing acridity, causing lips, mouth and throat tissues swelling if consumed fresh (Gouveia et al., 2018). Uracil and glycol protein lectin have been identified as compounds that could explain the acridity (i.e., irritation) of taro mucilage (Miyasaka et al., 2019). It happens in soluble form producing salts with potassium, sodium and $\mathrm{NH}_{4}$ ions, and also in insoluble form producing insoluble salts chiefly with calcium, but also with iron and magnesium (Savage et al., 2000). The threshold safe level of oxalate in any food is 71 $\mathrm{mg} / 100 \mathrm{~g}$ (Kumoro et al., 2014).

Variation in taro oxalate content is consistent and significantly correlated with the photosynthetic rate, carbohydrate metabolism and protein synthesis (Gouveia et al., 2018). Oxalate content in wild taro was reported higher as compared to cultivable taro (Buragohain et al., 2013). African taro cultivars (265.2 to $7725.5 \mathrm{mg} / 100 \mathrm{~g}$ ) were reported more acrid than the Pacific taro cultivars (317 to $445 \mathrm{mg} / 100 \mathrm{~g}$ ) (Kumoro et al., 2014) . Oxalate in taro leaves were reported higher as compared to taro petioles (Hang et al., 2011). Soluble oxalate in young taro leaves was reported higher as compared to old taro leaves which contain more insoluble oxalate than soluble oxalate (Oscarsson and Savage, 2007).

The amount of oxalate content in crop plant parts varies. For example, the oxalate-rich taro (Oscarsson and Savage, 2007) had varying levels of oxalates in the corms, leaves, and petiole. According to Hang et al. (2011), the total oxalate content of taro petioles ranged from 2400 to $4420 \mathrm{mg} / 100 \mathrm{~g}$ dry matter and from 2021 to $6342 \mathrm{mg} / 100 \mathrm{~g}$ in taro leaves.

\section{The acridity}

Acridity has been linked to calcium oxalate, which appears as fine needle-like crystals or raphides that can penetrate soft skin. Following that, an irritant present on the raphides (likely a protease) can cause tissue discomfort. The discomfort prevents animals from fully utilizing the uncooked taro plant (Tang and Sakai, 2021), and if the acridity is not properly removed, it is a deterrent to human use. Most foods of plant families contain high to excessively high oxalate concentrations are shown in Table 1 (Chai and Liebman, 2005). The consumption of oxalate-rich plants can negatively impact calcium oxalate stone formation (Chai and Liebman, 2005). Acridity content of taro plant is considered to be very low when it contains $\leq 50 \mathrm{mg}$, low 51 to $100 \mathrm{mg}$, intermediate 101 to $300 \mathrm{mg}$ (Ivancic and Lebot, 1999).

\section{Oxalate}

Oxalate is produced and accumulated in many crop plants and pasture weeds (Siener et al., 2020). Plant oxalate content can be affected by nitrogen sources, inorganic ion availability and other environmental factors (Libert, 1987a). Oxalate may play a role in ion balance and osmoregulation (Franceschi and Nakata, 2005). Oxalate oxidase and oxalate decarboxylase are present in some plants. Oxalate can be catabolized and the carbon recycled (Tooulakou et al., 2016). Oxalate accumulation by crop and pasture plants affect the nutritional qualities of food and feeds negatively.

\section{Oxalic acid}

Oxalic acid is a precursor in the conversion of plant calcium to calcium oxalate (Franceschi and Horner, 1980; 
Table 1. Oxalate rich food crops (Chai \& Liebman, 2005).

\begin{tabular}{lcc}
\hline Crop & Soluble oxalate $(\mathbf{m g} / \mathbf{g})$ & Total oxalate $\mathbf{( m g / g )}$ \\
\hline Phaseolus vulgaris (beans) & 38.80 & 547.90 \\
Glycyrrhiza glabra (Licorice) & 165.00 & 3569.30 \\
Trigonella caerulea (Blue fenugreek) & 72.30 & 1245.90 \\
Glycine max (Soybeans) & 37.90 & 276.80 \\
Ipomoea batatas (Sweet potato) & 76.70 & 495.60 \\
Abelmoschus esculentus (Okra) & 56.30 & 317.20 \\
Theobroma cacao (Cocoa) & 571.30 & 619.30 \\
Colocasia esculenta (Taro) & 85.00 & $278.00-574.00$ \\
Dioscorea (Yam) & $80 \%$ of total oxalate & $486.00-781.00$ \\
\hline
\end{tabular}

Oscarsson and Savage, 2007). Oxalic acid is a dicarboxylic acid with the chemical formula $\mathrm{C}_{2} \mathrm{H}_{2} \mathrm{O}_{4}$. It is a naturally occurring metabolite in plants and a component of all plant-derived human diets.

\section{OXALATE'S HEALTH AND ECONOMIC CONSEQUENCE}

\section{Oxalate's health effect}

Oxalic acid, a plant metabolite, is increasingly recognized as a food toxin with negative effects on human nutrition (Chakraborty et al., 2013). About $75 \%$ of all kidney stones are composed primarily of calcium oxalate (Chai and Liebman, 2005). Calcium oxalate crystal deposition in the kidneys (Khan and Glenton, 1995) and urinary tract (Mandel and Mandel, 1989) are two long-term effects of oxalate-containing foods. Furthermore, eating foods high in oxalate reduces calcium bioavailability (Amalraj and Pius, 2015). Ascorbic acid, glycine, and dietary oxalate are thought to be the main sources of urinary oxalate (Holmes and Assimos, 1998). Increased urinary oxalate, calcium, uric acid, and cysteine levels may aggravate kidney stone formation (Heilberg and Goldfarb, 2013).

Chronic kidney disease affects $10 \%$ of the world's population, with over 2 million people currently relying on dialysis or a kidney transplant to survive (Thomas, 2019). In developed countries with universal health care and large elderly populations, more than $80 \%$ of all kidney failure patients receive treatment (Jha et al., 2013). The number of cases of kidney failure will increase disproportionately in developing and low-income countries, where treatment with dialysis or kidney transplantation is prohibitively expensive, resulting in the death of over a million people each year from untreated kidney failure (Jha et al., 2013). The prevalence of kidney stone disease is variable by country, age group, gender, and race as shown in Figures 1, 2, 3 and 4 and Tables 2 and 3 (Chen et al., 2019; Romero et al., 2010; Chukwuonye et al., 2018).

\section{Oxalate's economic impact}

According to global facts about kidney stones, chronic kidney disease treatment in the United States is likely to exceed $\$ 48$ billion per year. Over the next decade, China's economy will lose $\$ 558$ billion due to the effects of heart and kidney diseases on death and disability. In Uruguay, the annual cost of dialysis was close to \$US 23 million. Chronic kidney disease costs more in England than breast, lung, colon, and skin cancer combined. Treatment for all current and new cases of kidney failure in Australia is estimated to cost $\$ 12$ billion. It is estimated that one in every five men and one in every four women in the world aged 65 to 74 have chronic kidney disease (https://www.kidney.org/kidneydisease/global-factsabout-kidney-disease).

\section{MECHANISMS OF CALCIUM OXALATE REDUCTION}

Physical, chemical, and genetic improvements can all help to reduce oxalates in food (Oscarsson and Savage, 2007). Physical processes, such as cooking, boiling, and soaking, can be used to remove oxalates from food. Cooking may improve digestibility, palatability, storage quality, and make root crops safer to eat. Chemical processes include calcium salt treatments, petroleum ether etc. Crop genetic improvement could be a long-term solution to reducing oxalate in crop plants.

\section{Physical methods}

Oxalates can be removed from food through physical methods such as cooking, boiling, and soaking. Cooking root crops may improve digestibility, palatability, storage quality, and make them safer to consume. Boiling significantly reduced the level of anti-nutritional factors, resulting in higher food quality. Boiling seven taro corm accessions for 5 minutes, for example, reduced oxalate levels by $16-78 \%$, tannin levels by $28-61 \%$, and phytate levels by $17-41 \%$ (Lewu et al., 2009). Savage and Mårtensson (2010) reported that boiling can reduce the oxalate content of a food if the water used for boiling is discarded. Boiling may also cause significant skin (epidermal) rupture and facilitate the leakage of soluble 
Table 2. Distribution of kidney stone disease cases by age and sex variability in Nigeria (Chukwuonye et al., 2018).

\begin{tabular}{lcccc}
\hline Age & Male & Female & Total & Percentage (\%) \\
\hline $1-10$ & 3 & 1 & 4 & 13.3 \\
$11-20$ & 2 & 2 & 4 & 13.3 \\
$21-30$ & 3 & 3 & 5 & 16.6 \\
$31-40$ & 4 & 4 & 8 & 26.6 \\
$41-50$ & 4 & 2 & 6 & 19.3 \\
$51-60$ & 1 & 2 & 3 & 10 \\
$61-70$ & 1 & 0 & 1 & 3.3 \\
Total & 18 & 13 & 31 & 100 \\
\hline
\end{tabular}

Table 3. Prevalence (\%) of kidney stone disease from population based studies in Nigeria (Chukwuonye et al., 2018).

\begin{tabular}{lcccc}
\hline State & Year of study & Sample size & Percentage & Male to female ratio \\
\hline Edo & 2009 & 520 & 23.3 & $1.9: 1$ \\
Osun & 2008 & 454 & 12.3 & $1: 0.8$ \\
Enugu & 2013 & 1941 & 11.4 & $1.6: 1$ \\
plateau & 2013 & 510 & 2.5 & $1.8: 1$ \\
Abia & 2014 & 328 & 13.4 & $1.4: 1$ \\
\hline
\end{tabular}

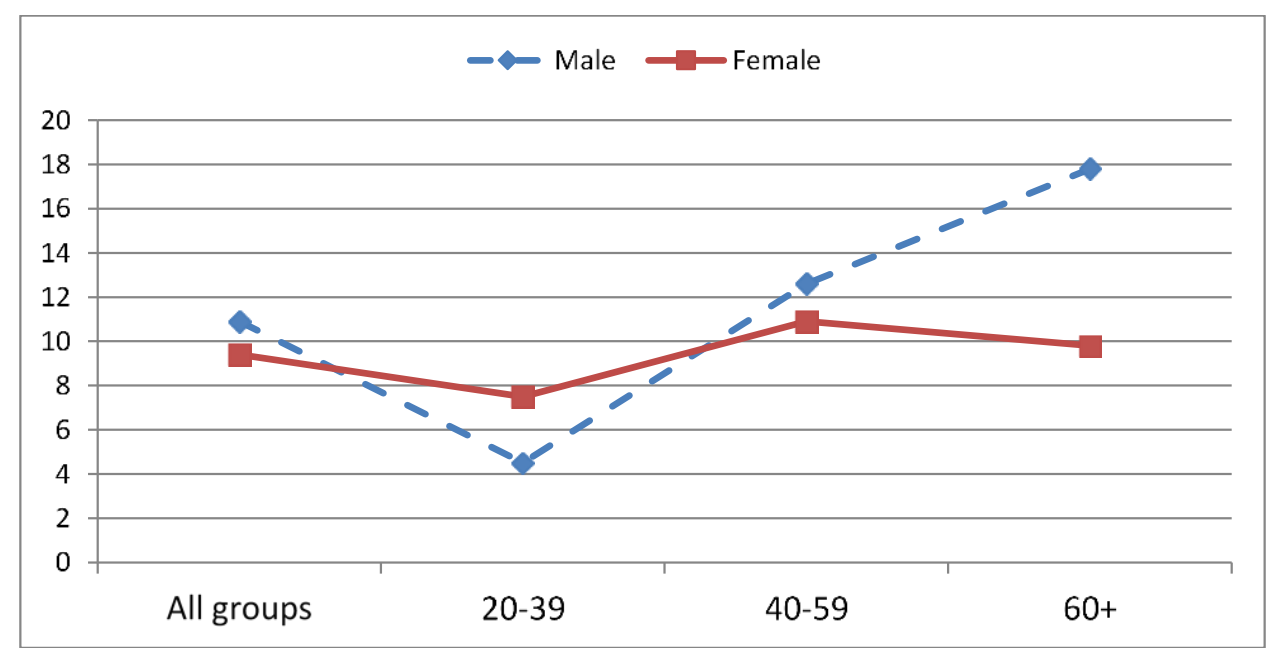

Figure1. Prevalence (\%) of kidney stone disease by gender and age group in United State of America (Chen et al., 2019).

oxalate into cooking water (Savage and Mårtensson, 2010). Cooking, as opposed to sun drying and soaking, is a better method for reducing oxalate concentration (Hang et al., 2011). Baking reduces the proportion of soluble oxalates from $73.90 \%$ fresh taro leaves to $21.50 \%$ in baked leaves (Oscarsson and Savage, 2007). Baking with milk further reduced oxalate levels to $21.40 \%$ of total oxalates (Zelalem and Shisho, 2017). Boiling mainly affects the soluble oxalate content of food but not the insoluble oxalate (Zelalem and Shisho, 2017). Baking a food on the other hand will result in an effective concentration of oxalates in the food due to water loss from the baked food (Shimi and Haron, 2014). Other physical methods to reduce the content of soluble oxalates include soaking, germination, and fermentation.

\section{Calcium treatments}

Consumption of high-calcium foods, the addition of 


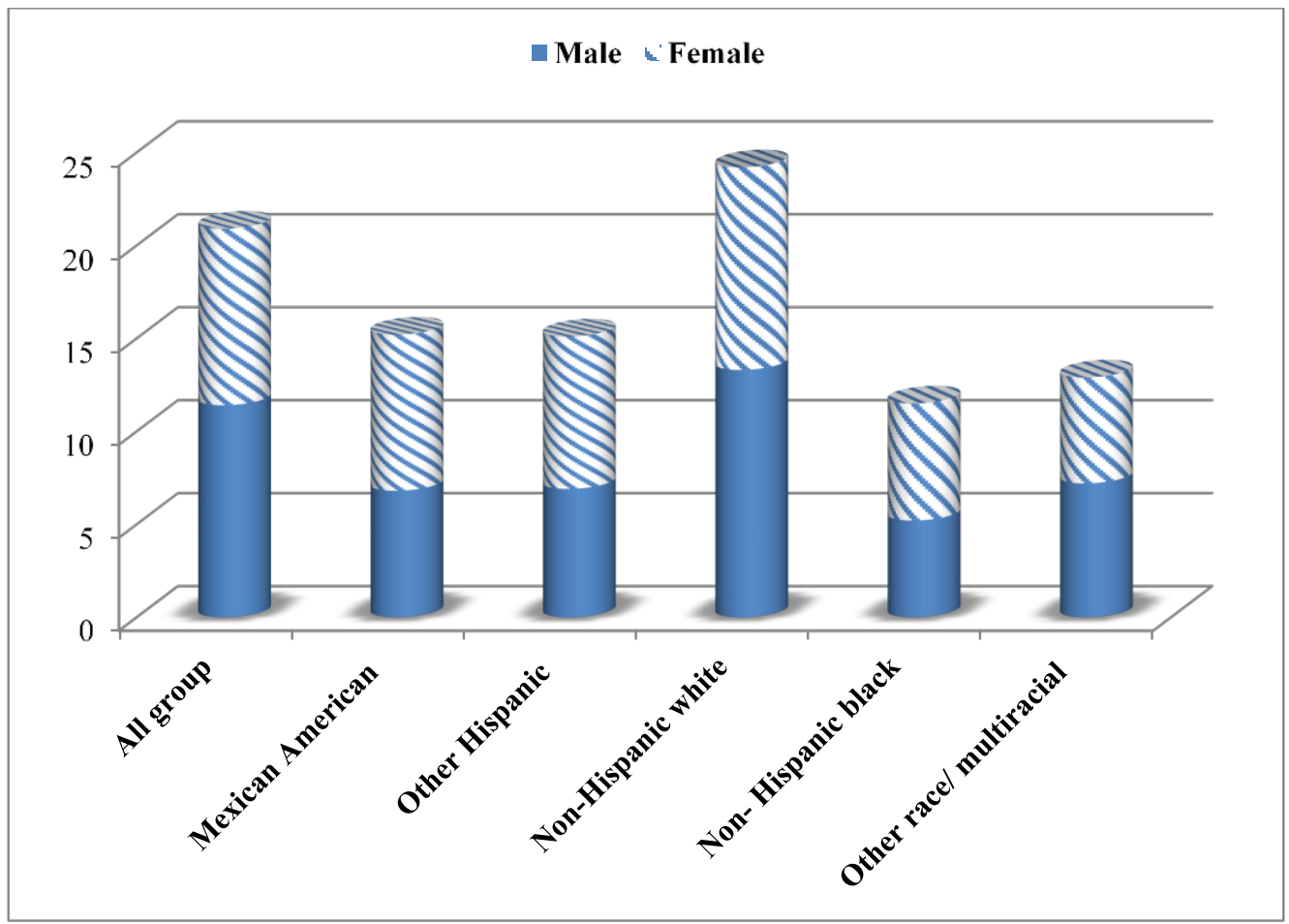

Figure 2. Prevalence (\%) of kidney stone disease by gender and race in United State of America (Chen et al., 2019).

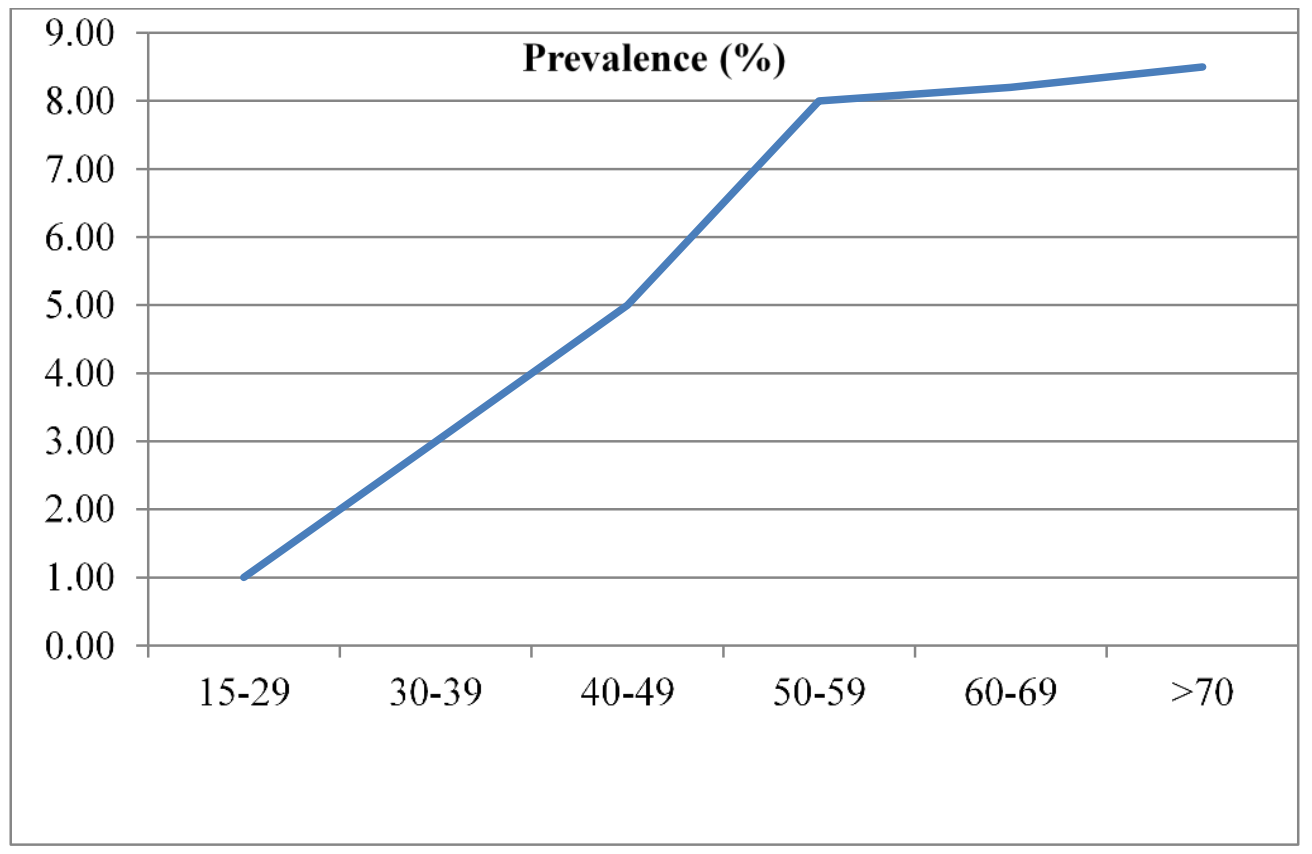

Figure 3. Iran kidney stone prevalence (\%) by age group (Romero et al., 2010).

calcium during cooking, or the addition of calcium salts during food manufacturing is other methods for converting soluble oxalates to insoluble oxalates. For instance, soaking in a $10 \% \mathrm{w} / \mathrm{w}$ baking soda solution for 2 hours, followed by 60 minutes of boiling at $90^{\circ} \mathrm{C}$ (Oscarsson and Savage, 2007), is the best condition for calcium oxalate reduction. The addition of calcium from milk during the cooking process, or calcium salts during manufacturing, 


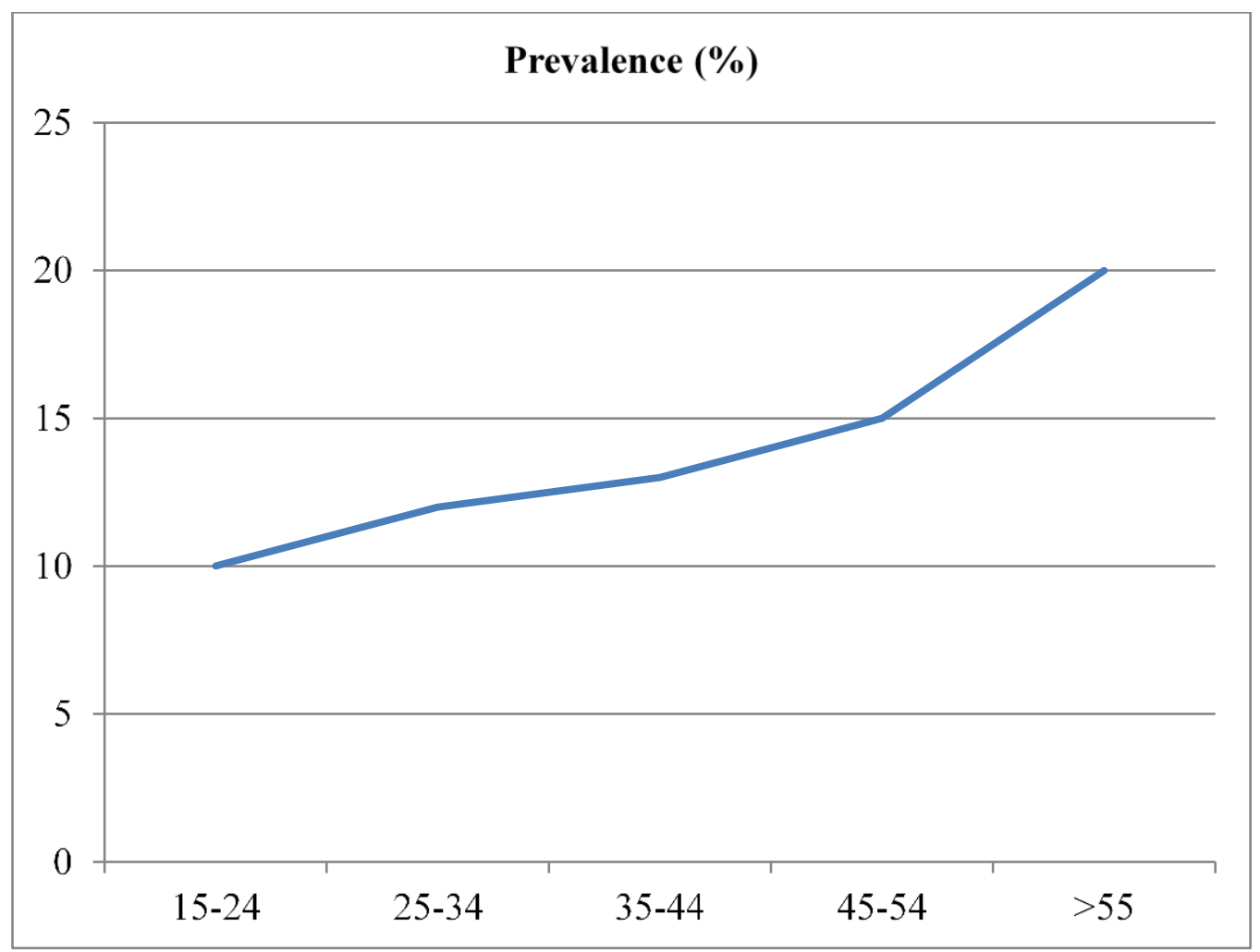

Figure 4. Turkey kidney stone prevalence (\% ) by age group (Romero et al., 2010).

for example, able to convert the soluble oxalates into insoluble oxalates (Faudon and Savage, 2014; Simpson et al., 2009). Calcium salts are widely accepted and used as acidity regulators, firming agents and stabilizers in processed foods (Msagati, 2013; Saltmarsh and Saltmarsh, 2013). A decrease in total soluble oxalate content of corms was reported during storage (Dana et al., 2017). Pre-treatments caused a reduction in anti-nutrients while the use of salt during pre-treatment further reduced the anti-nutrient content (Abiodun and Akinoso, 2014; Haileslassie et al., 2019; Haripriya et al., 2017).

\section{Genetic improvement}

Increasing the phytonutrient content of plant through selective breeding or genetic improvement is an effective disease prevention dietary option. However, the majority, if not all, of these bioactive compounds are bitter, acrid, or astringent, making them unpleasant for the consumer. Some have long been thought to be plant-based toxins. As a result, the food industry removes these compounds from plant foods on a regular basis through selective breeding and a variety of debittering processes. This creates a difficulty for functional food designers because increasing the content of bitter phytonutrients for health may be incompatible with consumer acceptance (Drewnowski and Gomez-Carneros, 2000).
The genetic diversity of taro germplasm is relatively higher, and leveraging this diversity could lead to the development of cultivars with improved disease resistance, yields, and corm quality. Several taro corm quality characteristics are highly variable and are almost certainly genetically determined (Lebot et al., 2004). The presence of low acridity (oxalate) is one of the most notable characteristics of this corm among those found in taro. Oxalate is a quantitative trait determined by a large number of genes with minor and cumulative effects. The research also confirmed that 25 putative genes are responsible for oxalate formation in spinach plants (Cai et al., 2018). Uracil and glycol-protein lectin have been identified as compounds that could explain the taro mucilage's acridity (Miyasaka et al., 2019).

Plants with high calcium oxalate content, such as spinach, have lower calcium bioavailability than plants with low calcium oxalate content, such as kale. Efforts have been made to identify germplasm (Ritter and Savage, 2007), growth conditions (Rahman and Kawamura, 2011; Rahman et al., 2010), breeding practices (Libert and Franceschi, 1987), and food preparation practices (Moreau and Savage, 2009) that result in taro plant with lower oxalate content. Otherwise, genetic modification may be able to reduce the oxalate content of plant foods (Nakata and McConn, 2007).

The oxalate content of plants is determined by the growing season (Rahman and Kawamura, 2011; Rahman 
et al., 2010). According to research, the summer grown spinach cultivar contained more oxalate than the autumn grown cultivar (Ghosh Das, 2011). Genetic variation studies for oxalate content in a Rheum genotype collection (Libert, 1987b) also revealed phenotypic variation of oxalate in rhubarb petioles. The same authors stated that low heritability and a long interval between generations are negative factors for future breeding of low-oxalate rhubarb cultivars. Low-oxalate genotypes, on the other hand, have vigorous growth and normal levels of titratable acidity (Libert, 1987b). Many studies have reported significant differences in oxalate content among crop species. For instance, Ajibola and Olapad, (2016) reported a significant difference in oxalate content among Africa yam bean seed accessions. Otegbayo et al. (2018) also reported yam varieties with an oxalate to calcium ratio of less than one suggesting calcium bioavailability in yam is cultivardependent due to oxalate content.

Plants have an uneven distribution of oxalate. For example, the leaves have the highest oxalate concentration, followed by the seeds, while the stems have the lowest (Libert, 1987b). According to studies, plants like Amaranthus (Bressani et al., 1993), Spinacia oleracea and Beta vulgaris (Concon, 1988; Fassett, 1973) have lower levels of oxalates in their petioles (stalks) than in their leaves. The quantity of oxalic acid in leaves is higher than in petioles in the buckwheat family, which includes Rheum rhabarbarum (rhubarb) (Libert, 1987b). According to Lilbert, (1987b), the oxalate content of rhubarb petioles increased with age, whereas rhubarb grown under forcing conditions accumulates less total oxalate but more watersoluble oxalate than rhubarb grown in the field.

The tropical root crops like Colocasia esculenta and Ipomoea batatas were found to have total oxalate content ranging from 278 to $574 \mathrm{mg} / 100 \mathrm{~g} \mathrm{FW}$ (Holloway et al., 1989) and $470 \mathrm{mg} / 100 \mathrm{~g} \mathrm{FW}$ (Mosha and Gaga, 1999), respectively. Total oxalate levels in Dioscorea (true yam) tubers were reported to range from 486 to $781 \mathrm{mg} / 100 \mathrm{~g}$ DW (Wanasundera and Ravindran, 1994), but this may be of little nutritional concern because 50 to $75 \%$ of the oxalates were in the water-soluble form and thus may leach out during cooking.

\section{SUMMARY AND CONCLUSION}

Taro is an annual herbaceous plant in the oxalate-rich food group. It is primarily grown for the corm, which is a staple food for millions of people. Oxalic acid is a naturally occurring plant metabolite that is found in all plant-derived human diets. It is becoming more widely recognized as a food toxin with detrimental effects on human nutrition. Consumption of oxalate-rich foods reduces nutrient bioavailability and contributes to kidney stones. Chronic kidney disease affects $10 \%$ of the global population, with over two million people currently requiring dialysis or a kidney transplant. The treatment of kidney and related diseases requires a significant financial investment that not everyone can afford. Oxalates, on the other hand, can be removed from food using physical methods such as cooking, boiling, and soaking. Cooking root crops may improve digestibility, palatability, storage quality, and safety. Soaking, germination, and fermentation are some other physical methods for reducing oxalate content. Consumption of high-calcium foods, as well as the addition of calcium during cooking, helps to reduce oxalate in our food. Crop genetic improvement could provide a long-term solution for lowering oxalate levels in crop plants. Using genetic engineering, oxalate-free varieties can be created. To conclude, people who have a history of kidney stones should avoid oxalate-rich foods. Boiling can reduce the soluble oxalate content of a food if the cooking water is discarded. Understanding the metabolism of oxalate can help farmers improve their crops. This review lays the groundwork for breeding taro cultivars with lower oxalate levels. In general, breeding to improve Taro oxalate level is an untapped opportunity that must be addressed.

\section{ACKNOWLEDGMENT}

We would like to thank Utobo Emeka Benjamin (Dr) and Samuel Chibuike Chukwu (Dr) for their insightful comments. The authors would also like to express their gratitude to the MoBreed project for their financial support in getting the journal published.

\section{CONFLICT OF INTEREST}

There are no conflicts of interest among the authors.

\section{REFERENCES}

Abiodun, O., \& Akinoso, R. (2014). Effect of delayed harvesting and pre-treatment methods on the antinutritional contents of trifoliate yam flour. Food chemistry, 146, 515-520.

Ajibola, G., \& Olapade, A. (2016). Physical, proximate and antinutritional composition of African yam bean (Sphenostylis stenocarpa) seeds varieties. Journal of Food Research, 5(2), 67-72.

Alcantara, R., Hurtada, W., \& Dizon, E. (2013). The nutritional value and phytochemical components of taro [Colocasia esculenta (L.) Schott] powder and its selected processed foods. Journal Nutrition \& Food Sciences, 3(3), Article Number 207.

Amalraj, A., \& Pius, A. (2015). Bioavailability of calcium and its absorption inhibitors in raw and cooked green leafy vegetables commonly consumed in India-An in vitro study. Food chemistry, 170, 430-436.

Bradbury, J., \& Holloway, W. (1988). Chemistry of tropical root crops: significance for nutrition and agriculture in the Pacific. ACIAR, Monograph No.6, 201p.

Bradbury, J., Bradshaw, K., Jealous, W., Holloway, W., \& Phimpisane, T. (1988). Effect of cooking on nutrient content of tropical root crops from the South Pacific. Journal of the Science of Food and Agriculture, 43(4), 333-342. 
Bressani, R., De Martell, E., \& De Godinez, C. (1993). Protein quality evaluation of amaranth in adult humans. Plant Foods for Human Nutrition, 43(2), 123-143.

Buragohain, J., Angami, T., Choudhary, B., Singh, P., Bhatt, B., Thirugnanavel, A., \& Deka, B. (2013). Quality evaluation of indigenous taro (Colocasia esculenta L.) cultivars of Nagaland. Indian Journal of Hill Farming, 26(2), 16-20.

Cai, X., Ge, C., Xu, C., Wang, X., Wang, S., \& Wang, Q. (2018). Expression analysis of oxalate metabolic pathway genes reveals oxalate regulation patterns in spinach. Molecules, 23(6), Article Number 1286.

Chai, W., \& Liebman, M. (2005). Oxalate content of legumes, nuts, and grain-based flours. Journal of Food Composition and Analysis, 18(7), 723-729.

Chakraborty, N., Ghosh, R., Ghosh, S., Narula, K., Tayal, R., Datta, A., \& Chakraborty, S. (2013). Reduction of oxalate levels in tomato fruit and consequent metabolic remodeling following overexpression of a fungal oxalate decarboxylase. Plant physiology, 162(1), 364-378.

Chen, Z., Prosperi, M., \& Bird, V. (2019). Prevalence of kidney stones in the USA: the National Health and Nutrition Evaluation Survey. Journal of Clinical Urology, 12(4), 296-302.

Chukwuonye, I., Ogah, O., Anyabolu, E., Ohagwu, K., Nwabuko, O., Onwuchekwa, U., \& Oviasu, E. (2018). Prevalence of chronic kidney disease in Nigeria: systematic review of population-based studies. International journal of nephrology and renovascular disease, 11, 165-172.

Concon, J. (1988). Food Toxicology: Principles and concepts, contaminants and additives: Marcel Dekker Inc.

Dana, E., García-de-Lomas, J., Verloove, F., García-Ocaña, D., Gámez, V., Alcaraz, J., \& Ortiz, J. (2017). Colocasia esculenta (L.) Schott (Araceae), an expanding invasive species of aquatic ecosystems in the Iberian Peninsula: new records and risk assessment. Limnetica, 36(1), 15-27.

Drewnowski, A., \& Gomez-Carneros, C. (2000). Bitter taste, phytonutrients, and the consumer: a review. The American Journal of Clinical Nutrition, 72(6), 1424-1435.

El-Monairy, O. (2015). Efficiency of Colocasia esculenta leaves extract and histopathological effects on Culex pipiens (Diptera: Culicidae). Journal of the Egyptian Society of Parasitology, 45(1), 85-92.

Fassett, D. (1973). Oxalates. Toxicants occurring naturally in foods. National Academy Press. Pp. 346-362.

Faudon, S., \& Savage, G. (2014). Manufacture of a low oxalate mitsumame-type dessert using rhubarb juice and calcium salts. Food and Nutrition Sciences, 5, 1621-1627.

Franceschi, V., \& Horner, H. (1980). Calcium oxalate crystals in plants. The Botanical Review, 46(4), 361-427.

Franceschi, V., \& Nakata, P. (2005). Calcium oxalate in plants: formation and function. Annual Review of Plant Biology., 56, 41-71.

Ghosh Das, S. (2011). The effect of Indian cooking style on the nutritional and anti-nutritional properties of spinach. Thesis, Lincoln University.

Gouveia, C., Ganança, J., Lebot, V., \& de Carvalho, M. (2018). Quantitation of oxalates in corms and shoots of Colocasia esculenta (L.) Schott under drought conditions. Acta Physiologiae Plantarum, 40, Article number 214

Haileslassie, H., Henry, C., \& Tyler, R. (2019). Impact of pretreatment (soaking or germination) on nutrient and anti-nutrient contents, cooking time and acceptability of cooked red dry bean (Phaseolus vulgaris L.) and chickpea (Cicer arietinum L.) grown in Ethiopia. International Journal of Food Science \& Technology, 54(8), 2540-2552.
Hang, D. T., Binh, L. V., Preston, T. R., \& Savage, G. P. (2011). Oxalate content of different taro cultivars grown in central Viet Nam and the effect of simple processing methods on the oxalate concentration of the processed forages. Livestock Research for Rural Development, 23(6), 1-9.

Haripriya, A., Radhika, V., \& Kavitha, K. (2017). Impact of pretreatments on the selected nutrient and anti-nutrient profile of Horse gram based traditional recipes. International Journal of Home Science, 3(1), 415-419.

Heilberg, I., \& Goldfarb, D. (2013). Optimum nutrition for kidney stone disease. Advances in chronic kidney disease, 20(2), 165-174.

Holloway, W., Argall, M., Jealous, W., Lee, J., \& Bradbury, J. (1989). Organic acids and calcium oxalate in tropical root crops. Journal of Agricultural and Food Chemistry, 37(2), 337341.

Holmes, R., \& Assimos, D. (1998). Glyoxylate synthesis, and its modulation and influence on oxalate synthesis. The Journal of urology, 160(5), 1617-1624.

Ivancic, A., \& Lebot, V. (1999). Descriptors for Colocasia esculenta: IPGRI.

Jha, V., Garcia-Garcia, G., Iseki, K., Li, Z., Naicker, S., Plattner, B., \& Yang, C. (2013). Chronic kidney disease: global dimension and perspectives. The Lancet, 382(9888), 260-272.

Khan, S., \& Glenton, P. (1995). Investigative urology: Deposition of calcium phosphate and calcium oxalate crystals in the kidneys. The Journal of Urology, 153(3), 811-817.

Kumoro, A. C., Putri, R. D. A., Budiyati, C. S., \& Retnowati, D. S. (2014). Kinetics of calcium oxalate reduction in taro (Colocasia esculenta) corm chips during treatments using baking soda solution. Procedia Chemistry, 9, 102-112.

Lebot, V., Prana, M., Kreike, N., Van Heck, H., Pardales, J., Okpul, T., \& Viet, N. (2004). Characterisation of taro (Colocasia esculenta (L.) Schott) genetic resources in Southeast Asia and Oceania. Genetic Resources and Crop Evolution, 51(4), 381 392.

Lewu, M., Adebola, P., \& Afolayan, A. (2009). Effect of cooking on the mineral and antinutrient contents of the leaves of seven accessions of Colocasia esculenta (L.) Schott growing in South Africa. Journal of Food, Agriculture \& Environment, 7(3\&4), 359-363.

Libert, B. (1987a). Breeding a low-oxalate rhubarb (Rheum sp. L.). Journal of horticultural science, 62(4), 523-529.

Libert, B. (1987b). Genotypic and non-genetic variation of oxalate and malate content in rhubarb (Rheum spp. L.). Journal of Horticultural Science, 62(4), 513-521.

Libert, B., \& Franceschi, V. (1987). Oxalate in crop plants Journal of Agricultural and Food Chemistry, 35(6), 926-938.

Mandel, N., \& Mandel, G. (1989). Urinary tract stone disease in the United States veteran population. II. Geographical analysis of variations in composition. The Journal of Urology, 142(6), 1516-1521.

Miyasaka, S., Bellinger, M., Kantar, M., Helmkampf, M., Wolfgruber, T., Paudel, R., \& Shintaku, M. (2019). Genetic diversity in taro (Colocasia esculenta). In: Genetic diversity in horticultural plants (pp. 191-215).

Moreau, A., \& Savage, G. (2009). Oxalate content of purslane leaves and the effect of combining them with yoghurt or coconut products. Journal of Food Composition and Analysis, 22(4), 303-306.

Mosha, T., \& Gaga, H. (1999). Nutritive value and effect of blanching on the trypsin and chymotrypsin inhibitor activities of selected leafy vegetables. Plant Foods for Human Nutrition, 54(3), 271-283. 
Msagati, T. (2013). The chemistry of food additives and preservatives: Wiley Online Library.

Nakata, P., \& McConn, M. (2007). Calcium oxalate content affects the nutritional availability of calcium from Medicago truncatula leaves. Plant science, 172(5), 958-961.

Nwanekezi, E., Owuamanam, C., Ihediohanma, N., \& Iwouno, J. (2010). Functional, particle size and sorption isotherm of cocoyam cormel flours. Pakistan Journal of Nutrition, 9(10), 973-979.

Oscarsson, K. V., \& Savage, G. P. (2007). Composition and availability of soluble and insoluble oxalates in raw and cooked taro (Colocasia esculenta var. Schott) leaves. Food Chemistry, 101(2), 559-562.

Otegbayo, B., Oguniyan, D., Olunlade, B., Oroniran, O., \& Atobatele, O. (2018). Characterizing genotypic variation in biochemical composition, anti-nutritional and mineral bioavailability of some Nigerian yam (Dioscorea spp.) land races. Journal of Food Science and Technology, 55(1), 205216.

Rahman, M., \& Kawamura, O. (2011). Oxalate accumulation in forage plants: Some agronomic, climatic and genetic aspects. Asian-Australasian Journal of Animal Sciences, 24(3), 439448.

Rahman, M., Ishii, Y., Niimi, M., \& Kawamura, O. (2010). Effect of application form of nitrogen on oxalate accumulation and mineral uptake by napiergrass (Pennisetum purpureum). Grassland Science, 56(3), 141-144.

Ritter, M., \& Savage, G. (2007). Soluble and insoluble oxalate content of nuts. Journal of Food Composition and Analysis, 20(3-4), 169-174.

Romero, V., Akpinar, H., \& Assimos, D. (2010). Kidney stones: a global picture of prevalence, incidence, and associated risk factors. Reviews in Urology, 12(2-3), e86.

Saltmarsh, M., \& Saltmarsh, M. (Eds.). (2013). Essential guide to food additives. Royal Society of Chemistry.

Savage, G., \& Mårtensson, L. (2010). Comparison of the estimates of the oxalate content of taro leaves and corms and a selection of Indian vegetables following hot water, hot acid and in vitro extraction methods. Journal of Food Composition and Analysis, 23(1), 113-117.
Savage, G., Vanhanen, L., Mason, S., \& Ross, A. (2000). Effect of cooking on the soluble and insoluble oxalate content of some New Zealand foods. Journal of Food Composition and Analysis, 13(3), 201-206.

Shimi, G., \& Haron, H. (2014). The effects of cooking on oxalate content in Malaysian soy-based dishes: Comparisons with raw soy products. International Food Research Journal, 21(5), 2019.

Simpson, T., Savage, G., Sherlock, R., \& Vanhanen, L. (2009). Oxalate content of silver beet leaves (Beta vulgaris var. cicla) at different stages of maturation and the effect of cooking with different milk sources. Journal of Agricultural and Food Chemistry, 57(22), 10804-10808.

Simsek, S., \& El, S. (2015). In vitro starch digestibility, estimated glycemic index and antioxidant potential of taro (Colocasia esculenta L. Schott) corm. Food Chemistry, 168, 257-261.

Tang, C., \& Sakai, W. (2021). Acridity of taro and related plants. In: Taro (pp. 148-164). University of Hawaii Press.

Thomas, N. (2019). Renal nursing: Care and management of people with kidney disease. John Wiley \& Sons.

Tooulakou, G., Giannopoulos, A., Nikolopoulos, D., Bresta, P., Dotsika, E., Orkoula, M., \& Klapa, M. (2016). Alarm photosynthesis: calcium oxalate crystals as an internal $\mathrm{CO} 2$ source in plants. Plant Physiology, 171(4), 2577-2585.

Wanasundera, J., \& Ravindran, G. (1994). Nutritional assessment of yam (Dioscorea alata) tubers. Plant Foods for Human Nutrition, 46(1), 33-39.

Zelalem, K., \& Shisho, H. (2017). Antinutritional levels of tubers of Colocasia esculenta, L. Schott (taro) and Dioscorea alata (yam) cultivated in Ethiopia. Journal of Nutrition and Food Sciences, 7(2), Article Number 585. 